\title{
FEMINISME LIBERAL \\ DALAM NOVEL SEPENGGAL BULAN UNTUKMU KARYA ZHAENAL FANANI
}

\author{
Musrifah \\ SMP Negeri 4 Pamekasan \\ musrifah.ums@gmail.com
}

\begin{abstract}
ABSTRAK
Tujuan penelitian ini difokuskan pada 1) pendeskripsian perjuangan perempuan dalam persamaan hak pendidikan, 2) pendeskripsian perjuangan perempuan dalam persamaan hak sipil, 3) pendeskripsian perjuangan perempuan dalam persamaan hak ekonomi pada novel Sepenggal Bulan Untukmu Karya Zhaenal Fanani. Teori utama yang digunakan adalah feminisme liberal menurut pemikiran Rosemarie Putnam Tong. Jenis Penilitian ini adalah penilitian kualitatif dengan pendekatan sosiologi, mimetik, dan feminis. Sumber data penelitian ini novel Sepenggal Bulan Untukmu karya Zhaenal Fanani. Teknik pengumpulan data penelitian ini adalah dokumentasi. Teknik analisis data menggunakan model Miles dan Huberman, yaitu reduksi data, penyajian data, penarikan kesimpulan, dan verivikasi. Interpretasi data yang digunakan adalah content analiysisy. Hasil penelitian adalah bentuk perjuangan tokoh perempuan pada novel Sepenggal Bulan Untukmu dalam memperjuangkan haknya, yang meliputi 1) hak dalam bidang pendidikan berupa perjuangan untuk memperoleh pendidikan yang tinggi, perjuangan memajukan dunia pendidikan; 2) perjuangan dalam hak sipil meliputi perjuangan memperoleh hak memilih keputusan, bependapat, hak milik, hak berorganisasi; 3) hak dalam mempeoleh kesejahteraan dengan cara ikut andil dalam perekomian.
\end{abstract}

Kata Kunci: feminisme liberal, perjuangan perempuan, hak

ABSTRACT

The purpose of this study is focused on: 1) the description of women's struggle for equal rights in education, 2) description of women's struggle for equal rights in civil, 3) description of the struggle for equal rights of women in the economy on a novel Sepenggal Bulan Untukmu by Zhaenal Fanani.The main theory is used according to the thought of liberal feminism Rosemarie Putnam Tong. This research type is qualitative research through sociological approach, mimetic and feminist. This research data source is novel Sepenggal Bulan Untukmu by Zhaenal Fanani. Data collection techniques of this study is documentation. Data were analyzed using models Miles and Huberman data reduction, data presentation, drawing conclusions and verification. Interpretation of the data used is content analysis.Results of the research is a form of struggle of female characters in the novel Sepenggal Bulan Untukmu in fighting for their rights, which 
include: 1 ) the right to education in the form of a struggle to obtain higher education, the advancement of education; 2) the struggle in the struggle for civil rights include the right to choose the decision, argue, property rights, the right to organize; 3) rights in geting welfare by way of taking part in a strong economy.

Keywords: Liberal Feminism, Women Struggle, Right

\section{PENDAHULUAN}

Dalam lingkungan budaya masyarakat, berkembang aturan tentang pembagian peran gender. Peran gender tersebut dapat diamati secara khusus pada anak laki-laki atau perempuan sehingga muncul stereotip tentang apa yang pantas bagi laki-laki atau perempuan. Berhubungan dengan peran gender tersebut, digambarkan bahwa perempuan adalah makhluk yang lemah, emosional, dan pasif. Sedangkan laki-laki adalah makhluk yang kuat, jantan, perkasa, dan rasional. Fakta tentang hal tersebut ada benarnya sehingga stereotip tidak mudah diubah (Darma, 2013:174).

Kenyataan lain di masyarakat adalah wanita berada di bawah dominasi pria. Mau tidak mau, keadaan ini telah berarti segalanya bagi wanita dalam sejarah kebudayaan manusia, baik yang sakral (yang diambil dari kitab-kitab suci atau mitos) maupun yang sekular (yang disusun secara ilmiah), senantiasa menunjukkan sebagai sejarah pria. Dari perspektif sejarah, jelas pria dan wanita tidak setara. Dikotomi nature dan cultur, pria-wanita menujukkan pemisahan dan stratifikasi di antara dua jenis kelamin tersebut (Abdullah, 1997:3). Dikotomi tersebut juga tercermin dalam pembagian pekerjaan pria dan pekerjaan wanita yang lebih dikenal dengan pembagian kerja secara seksual. Pada umumnya perempuan diberi peran dalam sektor domistik sedangkan laki-laki di sektor publik atau masyarakat. Hal tersebut merugikan perempuan (Darma, 2013:172).

Sejalan dengan uraian di atas, adanya perbedaan gender memunculkan ketidakadilan gender menjelma dalam berbagai bentuk isu-isu gender seperti marginalisasi, subordinasi, citra negatif perempuan, kekerasan, dan lain-lain. Fenomena tersebut diperkuat oleh penelitian yang dilakukan oleh Susanti pada tahun 2008 melalui studi lintas budaya. Penelitian tersebut menunjukkan bahwa peran perempuan di bidang publik seringkali tersembunyi di balik peran suami. Para perempuan sering kali berkorban atau dikorbankan dalam kelangsungan hidup rumah tangga (Susanti, 2008:1).

Permasalahan-permasalahan yang terjadi dalam suatu masyarakat seperti marginalisasi, subordinasi, citra negatif perempuan, kekerasan terhadap wanita, dan lain-lain merupakan realita yang bisa ditangkap oleh pengarang. Permasalahanpermasalahan itu merupakan hal yang menarik dan menyentuh perasaan pengarang sehingga ia menghasilkan karya sastra yang salah satunya bisa berbentuk novel. Novel merupakan salah satu bentuk refleksi dari kesadaran mental pengarang terhadap nilai-nilai 
yang hidup dan berkembang di tengah-tengah masyarakat. Novel tidak pernah lepas dari sistem sosial budaya yang melingkupinya. Novel memuat fenomena kemanusiaan yang kompleks.

Kesadaran akan ketimpangan struktur, sistem, dan tradisi dalam masyarakat atau pun yang tercermin dalam karya sastra kemudian melahirkan gerakan feminis. Gerakan itu untuk memperjuangkan kesetaraan perempuan dengan laki-laki. Eksplorasi feminisme tersebut dilakukan dengan berbagai hal, baik melalui sikap, penulisan artikel, puisi, novel, maupun berbagai media lain yang memungkinkan untuk dapat mentransformasikan gagasan atau pandangan sebagai bentuk kritik feminis terhadap situasi dan pandangan masyarakat (Darma, 2013:140). Berdasrakan uraian tersebut, Darma mempertegas bahwa karya sastra yang salah satunya adalah novel merupakan media yang memuat gagasan feminis terhadap pandangan dan situasi masyarakat.

Fenomena yang terlihat di masyarakat dan beberapa karya sastra melahirkan gagasan feminisme yang menuntut adanya kesetaraan perempuan dengan kaum laki-laki. Perjuangan feminisme menuntut kesetaraan hak-hak demokrasi serta ketidakadilan terhadap hak-hak dasar kehidupan kaum perempuan. Tujuan feminisme adalah meningkatkan kedudukan dan derajat perempuan agar sama atau sejajar dengan kedudukan serta derajat pria. Kedudukan perempuan merupakan kesadaran terhadap nasib, cita-cita, dan hak yang membuat perempuan bangkit untuk memperjuangkan kesetaraan dan menjadikannya sebagai perempuan kuasa. Perempuan kuasa dapat juga dideskripsikan sebagai perempuan yang menyadari bahwa ia mempunyai potensi yang sama dengan laki-laki dalam membangun negara dan masyarakat, perempuan yang berhasil menduduki posisi atau kedudukan yang sama bahkan yang lebih penting dari laki-laki di instansi-instansi penting. Jadi, gerakan feminis adalah suatu gerakan untuk mendobrak tataran sosial secara keseluruhan terhadap nilai-nilai perempuan agar mendapatkan kedudukan dan derajat yang sama baik dalam bidang sosial politik, ekonomi, dan hukum seperti yang diperoleh oleh laki-laki selama ini. Hal itu diperjelas oleh Darma (2013:141) bahwa Gagasan kaum feminis ingin memperjuangkan kaum perempuan untuk mengubah struktur hierarki antara laki-laki dan perempuan menjadi persamaan hak, status, kesempatan, dan peranan dalam masyarakat.

Hubungan gerakan feminis dengan karya sastra juga diperjelas oleh Priyatna (2014:21) melalui penelitiannya terhadap beberapa karya sastra karya N.H. Dini. Priyatna menyimpulkan bahwa karya sastra banyak mengandung problem yang menyinggung perempuan baik dalam kapasitasnya sebagai individu, anggota keluarga, ataupun dengan laki-laki. Dalam karya sastra ditemukan cerminan perempuan atas realita di masyarakat. Sejalan dengan perkembangan, bermunculan novel yang mengemban amanat gerakan feminisme. Salah satu novel yang isinya menaruh perhatian besar pada kedudukan dan peran wanita adalah novel karya Zhaenal Fanani yang berjudul Sepenggal Bulan Untukmu. Novel 
yang berjudul Sepenggal Bulan Untukmu karya Zhaenal Fanani ini merupakan novel populer.

Dengan bahasa yang gampang dicerna dan mengalir begitu saja, Zhaenal Fanani menyampaikan tema kegigihan tokoh perempuan dalam memperjuangkan hak- hak hidupnya dan kemajuan pendidikan di daerahnya. Melalui Tokoh-tokoh perempuan dalam novel Sepenggal Bulan Untukmu, Zhaenal Fanani memaparkan keberanian dan kegigihan tokoh-tokoh perempuan dalam menghadapi berbagai tantangan dan tekanan dari para lelaki yang tidak menyetujui perjuangannya dalam memperoleh hak-hak dasar kehidupan sebagai perempuan dan mempertahankan pendidikan untuk anak-anak.

Novel Sepenggal Bulan Untukmu karya Zhaenal Fanani ini pernah dianalisis oleh Wega Sukmawati Ariesta dengan judul Citra Perempuan dalam Novel Sepenggal Bulan Untukmu Karya Zhaenal Fanani: Kritik Sastra Feminis dan Implementasinya sebagai Bahan Ajar Sastra di SMA. Kajian tersebut lebih banyak mengungkap struktur cerita, mulai dari tokoh dan perwatakannya, setting, tema, dan alur. Untuk melengkapi kajian-kajian yang telah ada, novel Sepengal Bulan Untukmu karya Zhaenal Fanani akan dikaji dari sudut pandang yang berbeda daripada analisis yang terdahulu. Dalam penelitian ini, novel Sepenggal Bulan Untukmu akan dianalisis dengan tinjauan feminisme liberal Roesmarie Putnam Tong.

Menurut pemikiran Tong, feminisme liberal berkembang mulai abad ke-18. Gerakan feminisme pada abad tersebut mempunyai asumsi dasar bahwa tidak ada perbedaan antara laki-laki dan perempuan. Perempuan dan laki-laki mempunyai hak yang sama dalam mendapat pendidikan. Gerakan feminisme liberal pada abad ke-19 banyak upaya memperjuangkan perempuan untuk mendapatkan hak sipil dan ekonomi yang sama dengan laki-laki. Pada abad ke-20 feminisme liberal banyak bergerak dalam pembentukan organisasi-organisasi perempuan untuk menentang diskriminasi seksual di bidang politik, sosial, ekonomi, maupun personal.

Kajian feminisme liberal ini mempunyai kelebihan, di antaranya aspek kajian teori ini lebih spesifik dan terarah sehingga dihasilkan pemaparan yang rinci berdasarkan konsep tersebut. Konsep feminis liberal tentang pendidikan muncul berdasarkan pemikiran bahwa perempuan akan berkembang secara optimal sama seperti laki-laki apabila perempuan juga diberi pendidikan yang sama dengan laki-laki (Tong, 2010:21). Konsep feminis liberal tentang persamaan perempuan dan laki-laki tenyata tidak cukup diberikan pendidikan yang sama tetapi harus juga diberikan kesempatan yang sama dalam hak sipilnya yang meliputi hak berorganisasi, kebebasan berpendapat, hak untuk memilih, dan hak pribadi (Tong, 2010:36). Kemudian, berkembang lagi pemikiran bahwa perempuan harus melakukan pergerakan sehingga menyadari keterbatasan-keterbatasan dirinya dan memperbaiki 
kondisi di antaranya adalah ikut memikul beban keluarga yaitu ekonomi (Tong, 2010:43).

Berdasarkan uraian di atas, teori feminisme liberal pemikiran Roesmarie Putnam Tong sangat tepat untuk membedah novel Sepenggal Bulan Untukmu karya Zhaenal Fanani.

Dengan mengutip dari Geofe, Sugihastuti (2015:61) memaparkan feminisme merupakan kegiatan terorganisasi yang memperjuangkan hak-hak dan kepentingan perempuan. Jika perempuan sederajad dengan laki-laki, mereka mempunyai hak untuk menetukan dirinya sendiri sebagaimana yang dimiliki oleh kaum laki-laki selama ini. Feminisme merupakan gerakan kaum perempuan untuk memperoleh otonomi atau kebebasan menentukan dirinya sendiri. Feminis adalah gerakan kaum perempuan untuk menolak segala sesuatu yang dimarginalisasikan, disubordinasikan, dan direndahkan oleh budaya dominan, baik dalam bidang politik, ekonomi, maupun kehidupan sosial (Darma, 2013:140).

Darma (2013:141) juga menjelaskan tujuan pokok dari teori feminism, yaitu memahami penindasan perempun secara ras, gender, kelas, dan pilihan pilihan seksual, serta bagaimana mengubahnya. Teori feminisme mengungkap nilai-nilai penting individu perempuan beserta pengalaman-pengalaman yang dialami bersama dan perjuangan yang mereka lakukan. Selanjutnya, Darma memberikan penekanan pula bahwa feminisme merupakan upaya untuk mengakhiri penindasan dan eksploitasi perempuan yang manyangkut masalah kemanusiaan atau memperjuangkan hak-hak kemanusiaan.

Berdasarkan uraian di atas, bisa disimpulkan bahwa teori feminisme adalah pendekatan sastra yang digunakan untuk memperjuangkan kehidupan perempuan supaya merdeka dalam melaksakan aktivitas. Perempuan bebas mengungkapkan ide, jauh dari tekanan laki-laki, mempunyai harkat dan kebebasan dalam mengelola kehidupannya baik secara individu maupun secara sosial.

Feminisme terdiri atas beberapa aliran, yaitu feminisme liberal, feminisme radikal, feminisme marxis dan sosial, feminism psikoanalisis dan gender, feminisme eksistensialis, feminisme pastmodern, dan feminisme multikultural dan glabal (kulit hitam). Namun penelitian ini menggunakan salah satu dari aliran tersebut yaitu femenisme liberal. Teori feminisme liberal pemikiran Roesmarie Putnam Tong sangat tepat untuk membedah novel Sepenggal Bulan Untukmu karya Zhaenal Fanani.

Feminisme liberal ini mendasarkan pemikirannya pada konsep liberal yang menekankan bahwa wanita dan pria diciptakan sama dan mempunyai hak yang sama dan juga harus mempunyai kesempatan yang sama. Manusia berbeda dengan binatang karena nalar yang dimilikinya. Jadi, perempuan dan laki-laki sama-sama mempunyai nalar dan moral yang bisa dikembangkan dengan kemampuan rasionalitas tersebut perempuan bisa menjadi pembuat 
keputusan yang otonom dan pemenuhan kebutuhan diri sendiri (Tong, 2010:20-21).

Dalam The Subjection of Women, Mill memaparkan pemikirannya bahwa jika perempuan diberikan sepenuhnya hak atas kebebasan sipil serta kebebasan dalam ekonomi, masyarakat akan ikut merasakan manfaatnya (Tong, 2010:26). Argumentasi Mill yang lebih kuat tentang dorongan adanya gerakan perempuan untuk memperoleh hak pilih dijabarkan singkat oleh Tong (2010:28) bahwa jika perempuan diberikan pendidikan yang sama serta hak hukum yang sama dengan laki-laki, diberi pemahaman tentang kebaikan kolektif dan individual, maka perempuan juga bisa mengembangkan ketidakegoisannya seperti laki-laki.

Mill dan Harriet Tailor Mill lebih jauh menekankan agar persamaan perempuan dan laki-laki terwujud tidak cukup diberikan pendidikan yang sama tetapi juga harus diberikan kesempatan untuk berperan dalam ekonomi dan hak untuk berorganisasi, kebebasan untuk berpendapat, dijamin hak sipilnya yang meliputi, hak memilih dan hak milik pribadi hak dan sipil lainnya.

Pemikiran mereka berdua adalah dua-duanya menekankan pentingnya Pendidikan, Kemitraan dan Persamaan. Mill lebih menekankan pada pendidikan dan hak, sedangkan Taylor lebih menekankan kemitraan. Mill lebih jauh juga mempertanyakan superioritas laki-laki, menurutnya bahwa laki-laki itu tidak lebih superior secara intelektual dari perempuan. Pemikiran Mill yang juga menarik bahwa kebajikan yang ditempelkan pada perempuan seringkali merugikan perempuan karena perempuan tidak bisa menjadi diri sendiri, sebab ia akan menjadi orang yang dikehendaki masyarakat.

Berdasarkan uraian tesebut, gerakan feminisme menekankan agar persamaan perempuan dan laki-laki memperoleh pendidikan yang sama, memperoleh kesempatan untuk berperan dalam ekonomi dan hak untuk berorganisasi, kebebasan untuk berpendapat, dijamin hak sipilnya yang meliputi, hak memilih dan hak milik pribadi serta hak sipil lainnya.

METODE

Jenis penelitian ini adalah penelitian kualitatif. Penelitian kualitaif merupakan penelitian yang menggunakan data kualitatif yaitu berbentuk kata, kalimat, sketsa, dan gambar (Darmadi, 2014:44). Penelitian kualitatif adalah penelitian yang menghasilkan data deskriptif berupa kata-kata tertulis maupun lisan dari orang-orang dan pelaku yang diamati (Darmadi, 2014:287).

Pendekatan yang dipakai dalam penelitian ini adalah pendekatan sosiologis, mimetik, dengan teori feminis. Endaswara (2013:111) memaparkan bahwa setiap karya sastra merupakan cermin kehidupan sosial dan budaya. Jadi, sastra sebagai sebuah interaksi imajiner yang mencerminkan pola interaksi dalam dunia nyata.

Wiyatmi (2012:9) memaparkan bahwa mimetik berorientasi pada karya dalam hubungannya dengan kenyataan yang terjadi dengan masyarakat. Pendekatan mimetik memandang karya sastra 
sebagai peniruan alam atau kehidupan dan secara hirarkis karya seni berada di bawah kenyataan (Ratna, 2015:70). Jadi, pendekatan mimetik memahami hubungan karya sastra dengan realitas atau kenyataan. Penggunaan pendekatan sosiologis dan memisis ini digunakan untuk membantu memahami gender, feminis, dan status peranan perempuan dan yang lebih umum adalah memahami kehidupan manusia dalam masyarakat.

Sumber data dalam penelitian ini adalah karya sastra berupa novel yang berjudul Sepenggal Bulan Untukmu karya Zhaenal Fanani. Novel Sepenggal Bulan Untukmu karya Zhaenal Fanani diterbitkan tahun 2013 oleh DIVA Press. Data dalam penelitian ini berupa kata-kata, frasa, kalimat, klausa atau penggalan paragraf yang menunjukkan perjuangan perempuan dalam pendidikan, hak sipil, dan hak ekonomi yang terdapat dalam novel Sepenggal Bulan Untukmu karya Zhaenal Fanani.

Teknik pengumpulan data yang digunakan dalam penelitian ini adalah dokumen. Teknik dokumentasi merupakan teknik pengumpulan data dengan memanfaatkan sumber dokumen. Menurut Darmadi (2014:292) bahan dokumenter berupa otobiografi, surat-surat pribadi, buku atau catatan harian memorial kliping, data yang disimpan server dan flesdis dan data yang tersimpan website. Jadi, dalam penelitian ini data dokumen yang digunakan adalah dokumen tertulis yang berbentuk novel.

Teknis analisis data yang digunakan dalam penelitian ini adalah deskriptif analisis. Teknik deskriptif analisis dilakukan dengan cara mendeskripsikan fakta-fakta kemudian disusul dengan analisis, uraian, atau penjelasan. Proses analisis data dalam penelitian ini menggunakan langkah-langkah analisis model Miles dan Huberman. Miles dan Huberman menyatakan bahwa terdapat tiga macam kegiatan analisis data kualitatif yaitu data reduction (reduksi data), data display (penyajian data), conclusion drawing/verification (penarikan kesimpulan dan verivikasi ) (Sugiyono, 2011: 246).

PEMBAHASAN

Dalam novel Sepenggal Bulan Untukmu karya Zhaenal Fanani, terdapat perjuangan perempuan dalam memperoleh persamaan hak pendidikan meliputi perjuangan perempuan dalam memperoleh pendidikan yang lebih tinggi, perjuangan dalam menyadarkan masyarakat akan pentingnya pendidikan, perjuangan dalam mengembangkan pendekatan dan ide-ide inovatif yang menyenangkan bagi anak-anak, perjuangan dalam mengembangkan sarana dan prasarana, dan perjuangan dalam mengalahkan tantangan yang menghambat kemajuan dunia pendidikan.

Perjuangan perempuan dalam memperoleh hak sipil meliputi perjuangan perempuan dalam memperoleh kebebasan memilih keputusan, perjuangan perempuan dalam memperoleh hak berpendapat, hak milik, dan hak berserikat.

Perjuangan perempuan dalan hak ekonomi meliputi perjuangan perempuan dalam memperoleh hak untuk ikut andil dalam pengembangan perekonomian dan perjuangan perempuan dalam 
memperoleh penghasilan sendiri dengan cara bekerja. Dengan demikian, para perempuan tidak hanya menggantungkan hidupnya pada suami dan orang lain.

\section{Perjuangan Perempuan dalam Bidang Pendidikan}

Pendidikan adalah hal penting dan perlu diperjuangkan oleh kaum perempuan. Kaum perempuan merupakan orang yang terpenting dalam menggalakkan pendidikan yang dimulai dari rumah tangga sampai di lingkungan yang lebih luas, yaitu masyarakat. Perempuan yang berpendidikan tinggi dan berwawasan luas akan mampu mengatasi permasalahan, mengarahkan putraputrinya, bahkan berjuang untuk kemajuan pendidikan untuk orang banyak. Negara pun atas desakan Komite CEDAW memastikan adanya kesetaraan kesempatan bagi anak perempuan dalam pendidikan di semua tingkatan dan memastikan bahwa semua perempuan di daerah pedesaan dan daerah terpencil dapat memperoleh pendidikan yang bermutu.

Dalam novel Sepenggal Bulan Untukmu, perjuangan dalam pendidikan terlihat jelas. Tokoh perempuan, Khotimah, berjuang untuk mendapat izin dari orang tuanya untuk melanjutkan sekolah yang lebih tinggi. Dia tercatat sebagai siswa yang pintar di sekolah dasarnya.

"Seandainya kamu seorang anak laki-laki, tentu bapak tidak segelisah ini,” Katanya sambil memandang Khotimah.

"Imah sudah menawarkan diri pada bapak untuk bersekolah dan masuk sebuah pesantren. Tapi bapak tidak mengizinkan.”

Setu Larang memejamkan matanya. Khotimah telah menyelesaikan pendidikan sekolah dasar di desanya, meski saat itu hanya diikuti oleh delapan orang siswa. Namun ketika Khotimah mengajukan diri untuk melanjutkan sekolah di luar desa pesanggrahan dan memasuki sebuah pondok pesantren, ia menolak (1/SBU/FP/F/Hal.25).

Perempuan juga berhak atas segala akses yang mempermudah perempuan dalam memperoleh pendidikan sehingga perempuan bisa memperoleh pendidikan yang sama dengan laki-laki. Perjuangan dalam memperoleh pendidikan yang lebih tinggi juga dilakukan oleh tokoh perempuan Tumirah seperti tercantum pada kutipan berikut.

Setelah liburan selesai, ia meninggalkan Desa Serambi. Ia masuk sekolah SMP Negeri di Pasirian. Bekal nilai terbaik mengantar dirinya lolos seleksi. (2/SBU/FP/F/Hal.51). 
Perjuangan Tumirah mencerminkan perjuangan perempuanperempuan Indonesia yang menuntut pemerintah untuk memperhatikan dan mejalankan amanat salah satu hasil konvensi CEDAW tentang pengurangan angka putus sekolah pelajar putri dan penyelenggaraan program untuk gadis-gadis dan perempuan yang belum waktunya meninggalkan sekolah.

Seperti yang dikemukakan oleh Wollstonecraft bahwa perempuan dan laki-laki sama-sama mempunyai kapsasitas nalar sehingga perempuan pun bisa tumbuh menjadi manusia yang utuh. Jadi, perempuan bisa melakukan pekerjaan seperti yang dilakukan oleh laki-laki termasuk dalam berjuang memajukan pendidikan. Seperti yang terlihat pada tokoh Khotimah, Khotimah mempunyai semangat yang kuat untuk mendorong warganya agar mementingkan ilmu. Perjuangan Khotimah untuk menggugah hati para perempuan selalu dilakukan hampir setiap ada kesempatan. Dengan cara yang halus dan tidak menyinggung perasaan para perempuan yang diajak berbicara. Khotimah mengajak berbicara para perempuan yang datang ke tokonya untuk berbelanja. Khotimah dengan tidak secara langsung ingin menyadarkan para perempuan supaya menyekolahkan anak-anaknya.

“Dan anak lelakimu?”

"Ikut bapaknya ke hutan"

"Sekecil itu sudah ke hutan?"

" Daripada diam di rumah, Mak. Biar belajar untuk mencari bekal.”

"Bekalnya harus ilmu. Umurnya baru sepuluh tahun, bukan?”

Perempuan itu tertawa.“ Ilmu tidak menghasilkan uang, Mak.” (11/SBU/FP/F/Hal.117).

Setiap harinya selalu ada inovasi-inovasi yang dapat dilakukan. Dengan inovasi tersebut tanpa terasa setiap harinya dia menularkan ilmu pengetahuan kepada anak-anak. Sebuah perjuangan yang ringan bagi Tumirah karena Tumirah melakukannya dengan tulus sehingga perjuangan tersebut membuahkan hasil yang maksimal. Hal tersebut terdapat pada kutipan berikut.

Setiap pagi, ia berangkat ke sekolah lebih awal dari anak-anak. Perlahan-lahan ia membenahi ruangan yang selama ini dipergunakan sebagai ruang kelas. Setiap pagi, ia menempelkan gambar-gambar yang ia buat pada malam harinya. Tanpa diminta, mereka mulai menggambar sesuai yang mereka inginkan. Dan, Tumirah membiarkan mereka berjalan dengan imajinasinya (14 /SBU/FP/F/Hal.123).

Kegiatan yang dilakukan oleh Tumirah memberikan inprirasi bagi guru atau pelaku pendidikan yang senantiasa melakukan pembelaran yang inovatif. Kegiatan inovatif tersebut bisa berupa 
teknik atau metode yang menyenangkan, pendekatan kepada siswa, dan media-media yang digunakan untuk menyampaikan materi kepada anak-anak. Dengan pendekatan dan metode yang inovatif, anak-anak tidak terasa dalam mengikuti proses belajar mengajar, namun mereka dengan mudah menerima materi yang disampaikan oleh guru. Kegiatan-kegiatan yang inovatif akan bermanfaat bagi perkembangan belajar anak. Kegiatan inovatif tidak harus menghabiskan biaya mahal. Dengan biaya murah pun bisa terlaksana. Kegitan inovatif bisa menggunakan benda-benda dan lingkungan yang ada di sekitar sekolah.

Perjuangannya dalam bidang pendidikan tidak akan terwujud sepenuhnya tanpa sarana pendukung seperti gedung sekolah, alatalat tulis bahkan buku-buku bacaan. Papan, kapur, kain kanvas, kertas karton, kemucing pembersih, dan sapu merupakan sebagian dari sarana yang sangat dibutuhkan dalam dunia pendidikan. Tersidianya buku-buku bacaan sangat dibutuhkan untuk menunjang kemajuan pendidikan di sekolah. Keterbatasan adanya sarana pendudukung kegiatan pendidikan bisa disebabkan tidak sampainya bantuan pemerintah ke sekolah. Sekolah-sekolah yang berada di daerah terpencil sulit terjangkau oleh pantauan pemerintah. Dengan demikian, masyarakat harus berjuang untuk mengatasi masalah sarana tersebut.

Tumirah pun berpikir untuk mengusahakan pengadaan bukubuku bacaan anak-anak dan alat-alat tulis yang diperlukan dalam kegiatan belajar mengajar. Pengadaan buku-buku tersebut diusahakan sendiri oleh Tumirah dengan bantuan dana dari Mak Imah atau Khotimah. Hal tersebut terbukti pada kutipan berikut.

“Kalian bisa bertukar buku dengan teman kalian.” Kata Tumirah. "Pesan kakak, juga buku-buku itu jangan sampai robek atau hilang. Kakak juga membelikan kalian penghapus, papan, kapur berwarna, kain kanvas, kertas karton, kemucing pembersih, dan sapu dan mulai minggu depan kita akan mulai upacara setiap hari Senin” ( 24 /SBU/FP/F/Hal.148).

Perjuangan untuk memperoleh hal yang lebih baik dan lebih maju terkadang banyak mendapatkan rintangan. Perjuangan memajukan pendidikan di desa terpencil tidak jarang berbenturan dengan pandangan masyarakat yang masih tertutup untuk dunia pendidikan. Pandangan masyarakat desa belum menganggap pendidikan itu penting. Hak tersebut adalah rintangan yang berat untuk diatasi. Perlu perjuangan untuk merombak pandangan tersebut.

"Sejak aktivitasmu di sekolah dan di mushala, beberapa orang tua merasa penghasilan mereka menurun karena anak-anak tak mau lagi membantu mereka pergi ke hutan. Anak-anak lebih memilih datang ke sekolah atau 
mushala meski dengan jalan sembunyi-sembunyi atau dengan berbagai alasan” (26 /SBU/FP/F/Hal. 168).

Kutipan tersebut membuktikan bahwa kegiatan Tumirah dianggap menggangu kebiasaan anak-anak Pesanggrahan. Anakanak Pesanggrahan setiap hari membantu orang tua ke hutan dan membantu menambah penghasilan orang tua. Sejak adanya kegiatan Tumirah di sekolah, anak-anak mulai tertarik datang ke sekolah. Hal tersebut membuat warga marah dan menyuruh Tumirah agar menghentikan aktivitasnya.

Perempuan juga memiliki kekuatan fisik dan pikiran yang bukan budak atas hasratnya. Seorang perempuan akan membebaskan dirinya dari peran yang opresif sebagai orang yang lemah secara emosional. Dengan keinginannya untuk bebas dari segala keterkekangan, perempuan bisa berontak dan keras melawan siapa saja yang menjadi penghalangnya. Hal tersebut terlihat sekali pada tokoh Tumirah pada kutipan berikut.

"Tumirah memang pandatang. Tumirah juga hanya seorang perempuan, yang terkadang dipandang lemah. Tapi saya memiliki kekuatan yang tak bisa ditandingi siapapun.” Tumirah mendongak. "Allah!" (25/SBU/FP/F/ Hal. 161).

"Saya akan tetap hadir ke sekolah dan di mushalla selama anak-anak tidak meninggalkan saya. Apa pun risikonya!” Kata Tumirah dengan suara mantap (29/SBU/FP/F/Hal. 208).

Perempuan mempunyai kekuatan dan berhak memajukan pendidikan sekalipun harus bertaruh nyawa.

"Wirosabdo!” panggil Emak Imah.

"Apa hakmu hingga berani bicara akan menutup sekolah, hah?” (28 /SBU/FP/F/Hal. 187).

“ Dengar baik-baik Sukmotejo! Siapapun yang berani melangkahi halaman rumahku dan meminta Tumirah meninggalkan Pesanggrahan, maka dia harus melangkahi mayatku dahulu! Kau dengar, Sukmotejo! Harus melangkahi mayatku dahulu!”

“ Sukmotejo! percuma kau menghadapi paman Danuparang! Hadapi aku! Langkahi mayatku!” Emak Imah kembali berteriak. Suaranya melengking tinggi. Kulit wajahnya tertarik mengeras. Sepasang matanya membeliak. Tampaknya perempuan ini sudah di ambang puncak kemarahannya (31 /SBU/FP/F/Hal.389). 
Perjuangan Mak Imah dan Tumirah berhasil melewati banyak tantangan terutama tantangan dari kaum laki-laki yang menentang kegiatan Tumirah. Kaum laki-laki harus mengakui kekuatan, tekad, semangat, keuletan, kreativitas bahkan kemampuan berpikir yang dimiliki oleh dua tokoh perempuan, Tumirah dan Khotimah. Berkat perjuangan Tumirah yang dibantu oleh Khotimah, satu per satu masyarakat Pesanggrahan mulai mau menyekolahkan anakanaknya.

Sekolah pun mulai semarak dengan nyanyian
"Indonesia Raya”, “ Padamu Negeri”, dan kibaran
merah putih setiap hari senin. Anak-anak kembali
mengumandangkan adzan dan nyanyian puji-pujian
menjelang shalat Ashar dan Maghrib. Warga pun mulai
menjual kembali hasil hutan mereka kepada Emak
Imah. Pesanggrahan seolah hidup dari masa
kematiannya. (32/SBU/FP/F/Hal.405).

\section{Perjuangan Perempuan dalam Hak Sipil}

Perjuangan dalam hak sipil juga dilakukan oleh tohoh dalam novel Sepenggal Bulan Untukmu Karya Zhaenal Fanani. Hak Sipil yang diperjuangkan adalah hak memilih, hak kebebasan berpendapat, dan hak atas milik pribadi.

Perempuan memegang peranan penting dalam keberhasilan suatu generasi. Perempuan yang penuh kasih sayang, istri yang setia, dan pemikiran seorang ibu yang masuk akal, dan perempuan yang sungguh-sungguh terdidik, akan lebih cenderung untuk mengatur rumah tangganya, terutama mendidik anak-anaknya secara tepat. Hal itu terkandung dalam kutipan berikut.

Ia berpikir perempuan adalah tonggak yang akan menopang perjalanan sebuah generasi. Dan, ia ingin para perempuan Pesanggrahan menggeliat dari keadaanya yang vakum dan tidak mendapatkan hakhaknya yang semestinya mereka peroleh. Ia ingin agar para perempuan desanya tegak berdiri tanpa tekanan dari para suami mereka (2 /SBU/FSP/F/Hal.29-30).

Berdasarkan kutipan tersebut dapat dilihat bahwa perjuangan tokoh perempuan, Khotimah sangat besar. Keinginan untuk membebaskan perempuan dalam menentukan pilihan dan menjalani kehidupannya supaya tidak terkekang oleh suami. Khotimah ingin menyadarkan perempuan Pesanggrahan yang selama ini tidak memikirkan pendidikan anak-anaknya. Perempuan Pesanggrahan selalu mengikuti kehendak para suami agar anakanaknya ikut membantu bekerja di hutan.

Perjuangan untuk memperoleh hak memilih ditunjukkan oleh tokoh Khotimah. Khotimah berani memilih keputusan untuk menolak lamaran para lelaki yang ingin mempersuntingnya. Khotimah satunya-satunya perempuan yang melakukan hal itu 
padahal kebiasaan di Desa Pesanggrahan, perempuan menikah di saat mereka belum menjelang tujuh belas tahun. Khotimah sudah bulat dengan pilihannya untuk sementara tidak menikah dengan beberapa alasan. Namun, alasan Khotimah tidak bisa menghapus kekecewaan bapaknya, Setu Larang. Bahkan tindakan khotimah tentunya merupakan kelangkaan di Desa Pesanggrahan karena Khotimah menentukan pilihan yang tidak biasa dilakukan oleh perempuan Desa Pesanggrahan.

\section{Hak Menyampaikan Pendapat/Ide}

Perempuan adalah warga negara yang juga mempunyai kebebasan dalam menyampaikan ide, pendapat, atau pun pemikirannya. Dengan diberi kebabasan berpendapat, perempuan dapat berkembang menjadi manusia yang sempurna. Perjuangan dalam mencapai kebebasan menyampaikan ide atau pendapat tersebut dilakukan oleh tokoh perempuan dalam novel Sepenggal Bulan Untukmu. Hal tersebut terlihat pada kutipan berikut.

"Imah tak ingin seperti para perempuan desa ini, yang hanya menggantungkan hidup pada suami mereka.

“ Lalu apa maumu?”

"Imah ingin memiliki seorang suami yang bukan hanya sebagai pendamping hidup, tapi juga seseorang yang dapat memberi kebebasan (11/SBU/FSI/F/Hal. 26).

Keinginan untuk bebas yang dirasakan oleh Khotimah hampir sama dengan yang dirasakan oleh Tumirah. Berada di rumah besar majikannya, Tumirah merasa terbelenggu, terikat, dan tidak bisa besosialisasi dengan lingkungan serta tidak bisa mengembangkan ide, pendapat bahkan pemikiran dan kreativitasnya. Di rumah besar milik majikannya, Tumirah mengerjakan pekerjaan rumah yang rutin setiap hari. Pekerjaan itu hanya berkisar pada memasak, manyapu, mencuci, dan segudang pekerjaan rumah tangga. Rutinitas yang sangat membosankan dan tidak seseuai dengan jiwa Tumirah yang agresif, aktif, dan penuh dengan pemikiranpemikiran yang baru. Hal tersebut dapat terlihat pada kutipan berikut.

Lintasan tahun juga membuat Tumirah menyadari bahwa dirinya tak bisa terus terikat dengan dunia di hadapannya saat ini. Dunia yang menutup dirinya dari segala bentuk sosialisasi dengan lingkungan di sekitarnya. Dalam jiwanya terjadi pemberontakan. Dan, ia dapat memastikan dirinya terpenjara dan mulai merasa tak nyaman (16 /SBU/FSI/F/Hal. 80).

Di Desa Pesanggrahan, Tumirah mengembangkan kerativitasnya dengan cara mengelola sekolah, satu-satunya sekolah yang ada di desa itu. Tumirah memberi kebebasan kepada anakanak di sekolah untuk mengutarakan keinginannya dan 
khayalannya. Tumirah ingin anak-anak di sekolah menemukan dunianya dan tidak terbelenggu dengan ikatan aturan yang terlalu formal bagi anak-anak. Tumirah lebih akrab dengan anak-anak. Anak-anak pun lebih leluasa mengutarakan keinginan, ide, dan pikirannya. Hal itu terlihat pada kutipan berikut.

Mereka perlu perhatian dan kebebasan untuk mengutarakan keinginan. Mereka butuh ruang yang tidak membelenggu jalan pikiran dan khayalan mereka."

"Saya sudah minta izin kepada Pak Solikhan agar saya diberi kesempatan untuk bersama anak-anak dengan cara saya sendiri.” (17 /SBU/FSI/F/Hal. 112)

"Saya pikir saya tidak melakukan kesalahan.”

"Kau memasuki daerah orang lain!"

"Tapi Pesanggrahan termasuk wilayah Indonesia, bukan? Dan saya masih menjadi warga Negara Indonesia. Maka saya...."

"Cukup!” Sukmotejo memotong."Pesanggrahan masih wilayah Indonesia. Tapi Pesanggrahan punya aturan!”

“ Bisa saya dengar aturannya?”

" Saya mendengar desa ini belum memiliki seorang pemimpin yang disahkan oleh pemerintah,” (24 /SBU/FSM/F/Hal.166)

Perjuangan yang tampak dalam kutipan tersebut adalah perempuan juga berhak atas tempat tinggal. Perempuan juga warga negara Indonsia yang berhak ikut memiliki tanah air Indonesia. Perempuan berhak menempati bumi Indonesia apalagi dengan tujuan memajukannya.

\section{Hak Berserikat/Berkumpul}

Perempuan mempunyai hak dalam berserikat atau berkumpul untuk menjadi manusia yang maju dan berkembang.

Perjuangan Tumirah memang dimulai dengan pendekatan dan menganggap para gadis remaja sebagai sahabat. Dengan pendekatan Tumirah, gadis-gadis Pesanggrahan berani ke luar rumah, berkumpul, dan saling melebur serta mulai mengerti tetang pentingnya hidup bermasyarakat. Kebiasaan gadis Pesanggrahan mulai berubah.

Tumirah mendekati para gadis Pesanggrahan dengan menawarkan persahabatan. Ia berusaha menghindar dari pembicaraan soal pendidikan atau tentang pertentangan yang baru saja terjadi. Ia pun menjauh dari topik yang membuat mereka merasa tersingkir dari percaturan lingkungannya sendiri. Tumirah lebih banyak berbicara soal peran, hak, dan tanggung jawab seorang perempuan bagi para suami,desa, dan 
lingkungannya. Tapi sejauh ini, ia berusaha untuk tidak menggurui. Ia berbicara layaknya sahabat (29 /SBU/FSS/F/Hal.435).

\section{Perjuangan Perempuan dalam Hak Ekonomi}

Berdasarkan kutipan tersebut, dapat dipaparkan bahwa perempuan juga mempunyai hak untuk ikut mengembangkan perekonomian baik untuk kesejahteraan dirinya secara individu maupun untuk kemajuan atau kemakmuran orang banyak. Kemapanan ekonomi seorang perempuan akan membantu kemapanannya dalam menjalani hidup. Perempuan yang mempunyai penghasilan sendiri akan mudah memanfaatkan penghasilan tersebut sesuai keinginannya. Perempuan bebas berkativitas dengan penghasilan yang dimiliki. Perempuan yang mempunyai penghasilan sendiri bisa membantu orang-orang yang membutuhkan tanpa mengganggu perekonomian keluarga, bahkan bisa membantu kepentingan orang banyak seperti pembangunan, pemeliharaan lembaga-lembaga pendidikan, sarana dan prasarana sekolah. Perempuan yang memiliki bakat dalam bidang ekomoni akan mudah ikut andil dalam bidang perekonomian. Perempuan tersebut akan lebih mandiri dalam menata perekonomiannya. Perempuan tersebut tidak akan diam saja menerima nasib dan tidak akan selalu bergantung pada orang lain dalam hal ekonomi. Perempuan yang mempunyai bakat akan selalu beruasaha dan berjuang untuk meraih kesuksesan.

Tidak hanya bisa memenuhi kebutuhan hidupnya, namun dengan kekayaannya pula Khotimah bisa membantu orang- orang disekelilingnya yang membutuhkan dan mengembangkan lembaga pendidikan yang berguna untuk kepentingan generasi muda . Hal itu terlihat pada kutipan di bawah ini.
“Apa yang telah kamu lakukan di Pesanggrahan tidak bisa ditebus dengan apa pun, apalagi dengan sejumlah uang untuk membeli buku bacaan bagi anak-anak. Emak akan merasa berdosa jika tidak memenuhinya," Bisiknya lalu menjauhkan wajah Tumirah dari dadanya. Ia menatap wajah penuh air mata di hadapannya (3/SBU/FE/F/Hal.135).
"Pohon-pohon kelapa itu tidak ada manfaatnya selain diambil hasilnya setiap bulan. Tapi kalau Emak berikan untuk mushalla dan sekolah, barangkali manfaatnya lebih besar (5/SBU/FE/F/Hal.417). Untukmu karya Zhaenal Fanani dapat disimpulkan bahwa dalam novel tersebut terdapat perjuangan tokoh perempuan dalam memperoleh hak pendidikan, hak sipil, dan hak ekonomi. Perjuangan tokoh perempuan dalam hak pendidikan yaitu perjuangan perempuan untuk memperoleh pendidikan yang lebih 
tinggi, mendorong dan menyadarkan masyarakat akan pentingnya pendidikan bagi anak-anak, mengembangkan pendekatan dan ideide inovatif yang menyenangkan bagi anak-anak, mengembangkan pola berpikir dan wawasannya untuk memajukan lembaga pendidikan terutama dalam hal sarana dan prasarana, menghadapi dan mengalahkan tantangan yang menghambat dalam usaha memajukan dunia pendidikan.

Perjuangan perempuan dalam hak sipil meliputi kebebasan memilih keputusan untuk menunda pernikahan, menggiring warga untuk belajar menentukan keputusan yang positif demi kepentingan orang banyak, dan mengembalikan hak pilih perempuan dalam hal menentukan pasangan hidupnya. Perjuangan perempuan dalam hak berpendapat berupa perjuangan untuk memperoleh kebebasan dalam menyampaikan ide, pendapat, atau pun pemikirannya sebagai seorang istri, mengembangkan ide dan kreativitasnya untuk kemajuan masyarakat banyak, dan memperjuangkan kebebasan dan keberanian anak-anak di sekolah untuk mengutarakan keinginan dan khayalannya. Perjuangan perempuan dalam hak milik yaitu perjuangan perempuan untuk memiliki tempat tinggal dan ikut bertanggung jawab terhadap kemajuan daerah dan generasinya. Sedangkan perjuangan perempuan dalam hak berserikat adalah usaha untuk membebaskan kaum perempuan dan para gadis dari keterkungkungannya sehingga berani ke luar rumah, berkumpul, dan saling melebur serta mulai mengerti tetang pentingnya hidup bermasyarakat.

Perjuangan perempuan dalan hak ekonomi adalah ikut andilnya perempuan dalam pengembangan perekonomian yaitu dengan cara mencari pekerjaan untuk menopang hidupnya. Perjuangan perempuan di bidang ekonomi yang lain adalah dengan cara mengelola usaha pertokoan sehingga para perempuan tidak hanya menggantungkan hidupnya pada suami dan orang lain.

Perempuan perlu diberi kesempatan dan ruang untuk berperan aktif dalam segala bidang kehidupan, baik di bidang pendidikan, di bidang sipil, maupun bidang ekonomi. Yang perlu dipahami bahwa gerakan feminisme atau perjuangan para perempuan bukan berarti melawan kaum laki-laki. Perjuangan perempuan menginginkan adanya kesamaan kesempatan bagi perempuan untuk maju dan berkembang seperti kaum laki-laki.

\section{DAFTAR PUSTAKA}

Basir, Udjang. 2010. Sosiolinguistik: Pengantar Kajian Tindak

Berbahasa. Surabaya: Penerbit Bintang.

Abdullah, Irwan (Ed.). 1997. Sangkan Paran Gender. Ygyakarta: Pustaka Pelajar.

Darma, Yoce Aliah.2013. Analisi Wacana Kritis. Bandung: Yrama Widya.
Darmadi, Hamid. 2014. Metode Penelitian Pendidikan dan Sosial: Konsep Dasar dan Implementasinya. Bandung: Alfabeta.

Endaswara, Suwardi. 2013. Teori Kritik Sastra.Prinsip, Falasafah, dan penerapan. Yogyakarta : CAPS. 
Priyatna, Aquarini. 2014. Perempuan dalam Tiga Novel Karya N.H. Dini. Bandung: Matahari.

Ratna, Nyoman Kutha. 2015. Teori, Metode, dan Teknik Penelitian Sastra. Yogyakarta : Pustaka Pelajar.

Sugihastuti dan Suharto. 2010. Kritik Sastra Feminis Teori dan Aplikasi. Yogyakarta : Pustaka Pelajar.

Sugiyono. 2011. Metodologi Penelitian Kualitatif Kuantitatif dan $R \& D$.Bandung : Alfabeta.

Susanti, Emy. 2008. Ketimpangan Gender dan Ketidakberdayaan
Perempuan Miskin Perkotaan. Surabaya : Insan Cendikia.

Tong, Rosemarie Putnam. 2010. Feminist Thouht. Yogyakarta: Jalasutra.

Undang-Undang Republik Indonesia Nomor 7 Tahun 1984 tentang pengesahan konvensi Mengenai Penghapusan Segala bentuk Diskriminasi terhadap Wanita (CEDAW).

Wiyatmi. 2012. Kritik Sastra Feminis Teori dan Aplikasinya dalam Sastra Indonesia. Yogyakarta: Ombak (Anggota IKAPI). 